TABLE IV._Glucose Tolerance and Serum Insulins in Identical Twins of Diabetics According to Age at Diagnosis of Affected Twins

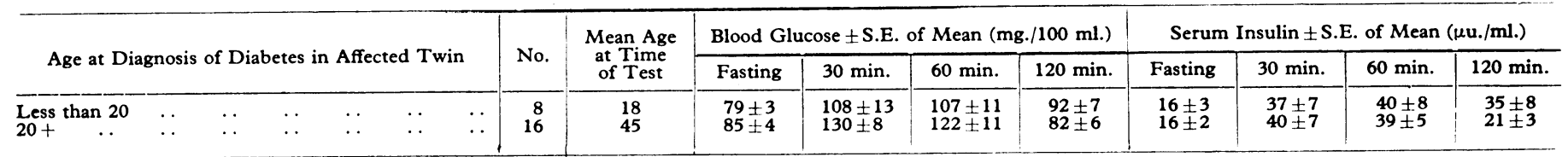

TABLE V.-Glucose Tolerance and Serum Insulins in Identical Twins of Diabetics Tested within 10 Years of, or More than 10 Years after, the Diagnosis of Diabetes in the Affected Twin

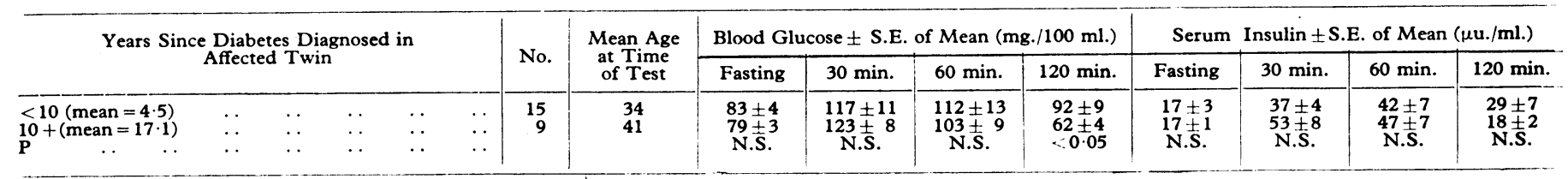

affected twin more than 10 years before we tested the other, yet the glucose and insulin values for these nine show no significant difference from the rest (except at 120 minutes, when it was actually better).

In one pair-No. 23 in Table I, which has been reported separately (Malins et al., 1970)-a twin showed normal glucose tolerance, even in late pregnancy, 26 years after her sister had developed diabetes and 20 years after she herself had shown a highly abnormal glucose tolerance test immediately after an appendicectomy.

All these results cast doubt on the idea of a progressive deterioration of glucose tolerance in identical twins of diabetics leading eventually to $100 \%$ concordance (Harvald, 1967). It is often assumed that all identical twins of diabetics are "prediabetic"-that is, certain to become diabetic. If this were so it would follow that diabetes was exclusively a genetic disease. Our results are consistent with the view that the aetiology of diabetes depends on several factors and that an inherited element is only one of the components in its causation, perhaps not such an important one as is often supposed (Pyke, 1970).

We are grateful to the British Diabetic Association for the support they have given in many ways to this work; also to our colleagues for referring cases and to the twins for their willing co-operation.

\section{REFERENCES}

Cerasi, E., and Luft, R. (1967). Acta Endocrinologica (Kobenhavn), 55, 330. Gottlieb, M. S., and Root, H. F. (1968). Diabetes, 17, 693.

Gottlieb, M. S., Soeldner, J. S., and Gleason, R. E. (1969). Diabetes, 18, Suppl. No. 1, p. 357

Harvald, B. (1967). Acta Medica Scandinavica, Suppl. No. 476, P. 17.

Harvald, B., and Hauge, M. (1963). Acta Medica Scandinavica, 173, 459.

Joslin, E. P., Root, H. F., White, P., and Marble, A. (1959). The Treatment of Diabetes Mellitus, 10th edn. London, Kimpton.

Malins, J., Cassar, J., and Pyke, D. A. (1970). Diabetes. In press.

Pyke, D. A. (1970). Postgraduate Medical fournal, 46, 604.

Pyke, D. A. and Taylor, K. W., (1967). British Medical fournal, 4, 21.

Smith, S. M., and Penrose, L. S. (1955). Annals of Human Genetics, 19, 273

Vallance-Owen, J. (1969). In Diabetes, ed. J. Ostman, p. 243. Amsterdam, Excerpta Medica.

\title{
Single-dose Therapy with Streptomycin and Sulfametopyrazine for Bacteriuria during Pregnancy
}

\author{
J. D. WILLIAMS, ${ }^{*}$ M.D., B.SC., M.R.C.PATH. ; EDNA K. SMITH, † M.B., M.R.C.o.G.
}

British Medical fournal, 1970, 4, 651-653

\begin{abstract}
Cummary: One hundred and sixty-three patients with bacteriuria in pregnancy were treated with a single dose of antibiotic. Four regimens were used: sulfadoxine (sulphormethoxine) 2 g., sulfametopyrazine 2 g., streptomycin $1 \mathrm{~g}$., and a combination of sulfametopyrazine $2 \mathrm{~g}$. and streptomycin $1 \mathrm{~g}$. The highest cure rate of $77 \%$ was achieved with streptomycin and sulfametopyrazine. The long-acting sulphonamides alone gave a cure rate of $55 \%$ while streptomycin alone eradicated $43 \%$ of the infections. Despite the high cure rate with combined therapy bacterial resistance developed in some cases.
\end{abstract}

\section{Introduction}

In selecting chemotherapy for treatment of bacteriuria during pregnancy the clinical and social conditions of the patients must be considered in addition to the infecting organisms. To avoid side effects and toxicity to the fetus the amount of

* Consultant Bacteriologist.

+ Research Registrar.

Dudley Road Hospital, Birmingham 18 chemotherapy should be the smallest necessary to eradicate the infection, and short courses are as effective as is prolonged therapy (Williams et al., 1965, 1968). The reluctance of patients to complete a course of treatment has recently been re-emphasized (Sprunt, 1970), particularly among the poor. Pregnant women of high parity tend not to take their iron tablets.

In our antenatal clinic, where $70 \%$ of patients belong to socioeconomic groups 9,10 , or greater, and $15 \%$ cannot understand English, there has been additional urgency to find an effective form of treatment which can be given in the clinic in one dose. The recent introduction of ultra-longacting sulphonamides which maintain therapeutic levels of sulphonamide in the urine and serum for one week led us to try two of these compounds, sulfadoxine $\ddagger$ and sulfametopyrazine, for this purpose. We have also treated a few patients with streptomycin alone, and finally a group with a combination of sulfametopyrazine and streptomycin. In all cases only one dose of the drug was given.

$\ddagger$ The name sulfadoxine replaced sulphormethoxine as the approved title from January 1969. 


\section{Methods}

From all women attending the antenatal clinic at Dudley Road Hospital a midstream specimen of urine is collected for detection of significant bacteriuria, which is defined as more than 100,000 organisms per ml. of urine. Positive urines are detected with the blotting-paper strip test as a screening method, positive results being confirmed by surface viable counting. Patients whose urine is positive are then recalled to the clinic and a further midstream specimen is taken to confirm that finding. The 163 women with confirmed persistent bacteriuria were then treated with the following regimens: 71 with $2 \mathrm{~g}$. of sulfadoxine orally, 24 with $2 \mathrm{~g}$. of sulfametopyrazine orally, 21 with $1 \mathrm{~g}$. of streptomycin orally, and 47 with $1 \mathrm{~g}$. of sulfametopyrazine orally and $1 \mathrm{~g}$. of streptomycin intramuscularly. Follow-up specimens of urine were collected two weeks after treatment and monthly thereafter until delivery, and were examined bacteriologically. Further treatment was prescribed when necessary.

Organisms isolated were identified by routine bacteriological methods. Sensitivity of the organisms isolated before and after treatment was determined for the appropriate antimicrobial agent by tube dilution methods. Serotyping of Escherichia coli strains was performed to elucidate treatment failures.

\section{Results}

The organisms isolated were predominantly $E$. coli; their distribution in the four groups of patients is shown in Table I. The numbers of strains of bacteria resistant to $200 \mu \mathrm{g}$. of sulphonamide per $\mathrm{ml}$. or to $50 \mu \mathrm{g}$. of streptomycin per ml. are also shown in Table I. The sulphonamide-resistant strains in the three sulphonamide groups did not differ significantly in number. The incidence of streptomycin-resistant strains was about $5 \%$ in each of the groups receiving streptomycin.

Response to Treatment.-In calculating the cure rate of each form of treatment failures due to reinfection by a different bacterial strain have been excluded. Treatment was regarded as successful if the original organism had been cleared from the urine. The long-acting sulphonamides alone gave similar results, clearing from one-half to two-thirds of the infection, with a few relapses at six weeks (Table II). Streptomycin by itself cleared only $43 \%$ of the organisms and there were no relapses. The highest initial cure rate of $77 \%$ was achieved with the combination of sulfametopyrazine and streptomycin. Of 47 patients receiving the combined therapy, 36 were clear of the original organism in two weeks. Two of

TABLE I.-Organisms and Sensitivity Patterns Isolated from the Four Groups of Patients Treated

\begin{tabular}{|c|c|c|c|c|c|c|}
\hline \multirow[b]{2}{*}{ Compound Used } & \multirow[b]{2}{*}{$\ddot{\ddot{8}}$} & \multirow[b]{2}{*}{ 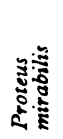 } & \multirow{2}{*}{ 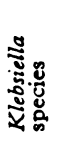 } & \multirow[b]{2}{*}{ ర్తే } & \multicolumn{2}{|c|}{ No. of Strains Resistant to: } \\
\hline & & & & & $\begin{array}{l}200 \mu \mathrm{g} . \\
\text { Sulphonamide } \\
\text { per ml. }\end{array}$ & $\begin{array}{l}50 \mu \mathrm{g} . \\
\text { Streptomycin } \\
\text { per ml. }\end{array}$ \\
\hline \multirow[t]{2}{*}{$\begin{array}{l}\text { Sulfadoxine } \\
\text { Sulfametopyrazine . } \\
\text { Streptomycin } \\
\text { Sulfametopyrazine } \\
\text { and streptomycin }\end{array}$} & $\begin{array}{l}62 \\
23 \\
18\end{array}$ & $\begin{array}{l}5 \\
1 \\
1\end{array}$ & $\begin{array}{l}6 \\
1 \\
2\end{array}$ & $\begin{array}{l}73^{*} \\
25+ \\
21\end{array}$ & $\begin{array}{c}14 / 43(32 \%) \\
8 / 24(33 \%) \\
-\end{array}$ & $\frac{\bar{z}}{1 / 2 \overline{1(5} \%)}$ \\
\hline & 37 & 4 & 6 & 47 & $18 / 47(38 \%)$ & $2 / 38(4 \%)$ \\
\hline
\end{tabular}

* 2 patients had 2 organisms in urine.

+1 patient had 2 organisms in urine.

TABLE II.-Response to Treatment of the Four Groups of Patients Excluding the Reinfections which Occurred. Percentages in Parentheses.

\begin{tabular}{ll|c|c|c|}
\hline & $\begin{array}{c}\text { No. of Patients } \\
\text { Treated }\end{array}$ & $\begin{array}{c}\text { Clear of Original } \\
\text { Infection at } \\
\text { 2 Weeks }\end{array}$ & $\begin{array}{c}\text { Clear of Originat } \\
\text { Infection at } \\
6 \text { W eeks }\end{array}$ \\
\hline $\begin{array}{l}\text { Sulfadoxine } \\
\text { Sulfametopyrazine }\end{array}$ & $\cdots$ & 71 & $39(55)$ & $37(52)$ \\
$\begin{array}{l}\text { Streptomycin } \\
\text { Sulfametopyrazine and } \\
\text { streptomycin .. }\end{array}$ & $\cdots$ & 24 & $16(66)$ & $15(62)$ \\
9 & 47 & $36(73)$ & $33(70)$ \\
\hline
\end{tabular}

TABLE III.-Comparison of Response to Treatment in Relation to Sensitivity to TABLE III.-Comparison of Response to Treatment in Relation to Sensitivity to
Sulphonamide in Sulfametopyrazine and Combined Streptomycin in the Streptomycin and Combined Therapy Oroups

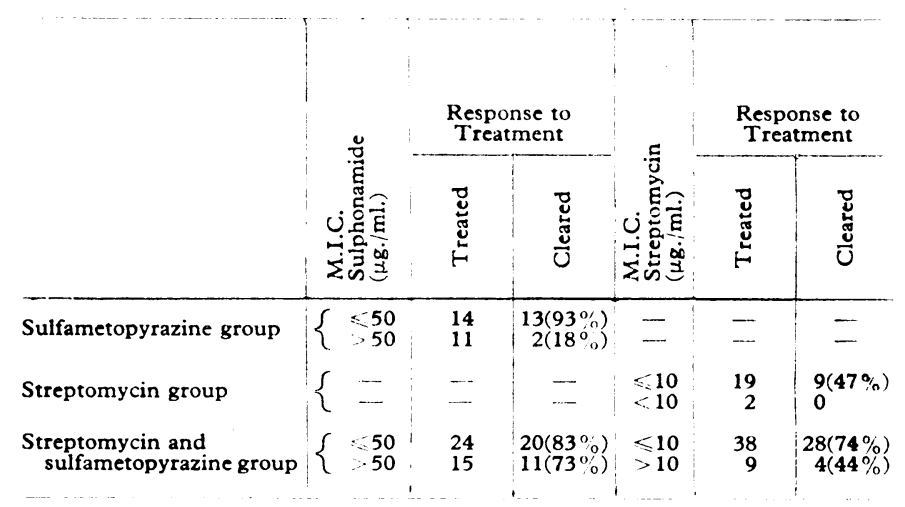

these were already reinfected with a new organism at this time, and six weeks after treatment three further patients had acquired a fresh infection necessitating further treatment. In three patients the original organism reappeared in the sixweek specimen.

Sensitivity and Response to Treatment.-The relationship between the minimal inhibitory concentration (M.I.C.) of the organism and response to treatment in three of the groups of patients is shown in Table III. In the sulfametopyrazinetreated patients an M.I.C. of $50 \mu \mathrm{g}$. of sulphonamide per $\mathrm{ml}$. or more was found in 11 patients and only two responded to treatment. In the streptomycin-treated group the two strains resistant to $10 \mu \mathrm{g}$. streptomycin per $\mathrm{ml}$. did not respond to treatment though $47 \%$ of the sensitive strains were cleared. The addition of streptomycin to sulfametopyrazine affects the response of the sulphonamide-resistant organisms. With sulphonamide alone only $18 \%$ of sulphonamide-resistant organisms responded: with combined thcrapy the response rate was $73 \%$. The effect of sulphonamide on the cure rate produced by streptomycin is also shown. With streptomycin alone the cure rate was only $47 \%$ when treating streptomycinsensitive organisms. The addition of sulphonamide raised the cure rate to $74 \%$.

Development of Resistance during Combined Therapy.-Of the 11 infections which persisted despite combined therapy two developed resistance to sulphonamide during therapy and one developed resistance to streptomycin. Two of the three patients who relapsed with the original organism six weeks after treatment developed resistance to sulphonamide. Of the five reinfections which occurred, three showed changes in sensitivity pattern; two cases infected with a sulphonamidesensitive strain now had a sulphonamide-resistant strain, and in one case a sulphonamide-resistant strain was replaced by a strain that was sulphonamide-sensitive.

\section{Discussion}

Many compounds have been used to treat bacteriuria of pregnancy, and the duration of the course of treatment has varied (Whalley, 1967; Williams et al., 1968). Most effective compounds, however, give a cure rate of about $70 \%$. In most series there is a group of persistent infections which respond poorly if at all to chemotherapy. Consequently, ease of administration, lack of toxicity, and cost become important factors in the choice of antibiotic. Our objective in this study was to find a form of minimal single-dose treatment which would give a cure rate similar to that obtained with more commonly used forms of therapy.

The incidence of sulphonamide resistance among urinary pathogens appears to vary considerably in different areas of the United Kingdom. This is sometimes ascribed to the difficulties involved in accurate assessment of sulphonamide sensitivity, but the incidence of sulphonamide resistance in Bir- 
mingham antenatal patients is $34 \%$ (Table I) compared with $13 \%$ in London (Williams and Leigh, 1966). An identical technique was used in Birmingham and London. The large number of sulphonamide-resistant strains is probably the reason for the relatively poor cure rate obtained with longacting sulphonamide alone (Table II). Grüneberg and Brumfitt (1967) found a cure rate of $88 \%$ with sulfadoxine when treating general-practice patients; almost all of these organisms were sulphonamide-sensitive.

The failures of treatment with sulfametopyrazine occurred in sulphonamide-resistant strains (Table III). Possibly in areas with a high incidence of sulphonamide-sensitive strains the cure rate would be satisfactory with sulphonamide alone, but only $52(55 \%)$ of our 95 patients responded.

Streptomycin produces very high bactericidal levels in the urine (Buggs et al., 1946), and $95 \%$ of the organisms isolated were sensitive to streptomycin. Unfortunately, the action is short-lived, and of the 20 patients treated only nine responded. The results with combined therapy were more successful than the other regimens, three-quarters of the infections being eradicated (Table II). This improvement in cure rate was achieved by streptomycin, raising the cure rate of sulphonamide-resistant strains from 18 to $73 \%$ (Table III). Alternatively, the sulfametopyrazine raises the cure rate of streptomycin-sensitive strains from 47 to $74 \%$. Development of resistance during treatment is a feature of treatment with both sulphonamide and streptomycin and occurred even when both compounds were used simultaneously.

Toxicity must be considered with particular care in pregnancy because of the risk of damage to the fetus. The possible effects on the neonate from sulphonamide therapy arise from jaundice due to competition between sulphonamide and bilirubin for binding sites (Odell, 1959; Dunn, 1964). None of our patients, however, was more than 36 weeks pregnant when treated. None of the mothers showed adverse reactions to the sulphonamide.

Neonatal deafness has been recorded following treatment of the mother with streptomycin and its analogues for tuberculosis, but the treatment in these cases has been prolonged and the incidence very low (Adamsons and Joelsson, 1966). In the children studied by Conway and Birt (1965) very large doses of streptomycin given to the mother sometimes produced abnormalities in eighth-nerve function tests, but no cases of perceptive deafness were found. It is unlikely that the dose we have used would have a perceptible effect on the fetus.

We are grateful to Mr. W. MacDougall, Mr. G. Mitchell, and Miss A. Reynolds for allowing us to study patients under their care; Mr. A. P. Condie for help in treating patients with sulfadoxine: Miss G. Warner for technical help; and Dr. J. C. P. Weber, of Pharmitalia, for supplies of sulfametopyrazine (Kelfizine).

\section{REFERENCES}

Adamsons, K., and Joelsson, I. (1966). American Fournal of Obstetrics and Gynecology, 96, 437.

Buggs, C. W., Pilling, M. A., Bronstein, B., and Hirshfield, J. W. (1946). fournal of Clinical Investigation, 25, 94.

Conway, N., and Birt, B. D. (1965) British Medical fournal, 2, 260

Dunn, P. M. (1964). Fournal of Obstetrics and Gynaecology of the British Commonwealth, $71,128$.

Grüneberg, R. N., and Brumfitt, W. (1967). British Medical fournal, 3, 649.

Odell, G. B. (1959). Fournal of Pediatrics, 55, 268.

Sprunt, J. G. (1970). Prescribers' fournal, 10, 55.

Whalley, P. (1967). American fournal of Obstetrics and Gynecology, 97, 723.

Williams, J. D. Brumfitt, W., Leigh, D. A., and Percival, A (1965). Lancet, 1,831 .

Williams, J. D., and Leigh, D. A. (1966). British fournal of Clinical Practice, 20, 177 .

Williams, J. D., et al. (1968). In Urinary Tract Infection, ed. F. O'Grady and W. Brumfitt, p.160. London, Oxford University Press.

\title{
Thyroid Scanning with ${ }^{131} \mathrm{Cs}$
}

\author{
I. P. C. MURRAY, ${ }^{*}$ M.D., F.R.C.P.ED., M.R.A.C.P. ; R. D. H. STEWART, $\dagger$ M.D., M.R.C.P. \\ :J. S. INDYK, $\ddagger$ F.R.C.S., F.R.A.C.S.
}

British Medical fournal, 1970, 4, 653-656

\begin{abstract}
Cummary: Scanning of the thyroid gland after the administration of radioactive caesium $\left({ }^{131} \mathrm{Cs}\right)$ was performed in $\mathbf{4 5}$ patients; in 38 of these it had been shown that a thyroid nodule failed to accumulate sodium pertechnetate $\left({ }^{99 m} \mathrm{Tc}\right)$ or sodum iodide $\left({ }^{131} \mathrm{I}\right) .{ }^{131} \mathrm{Cs}$ was concentrated in the nodule to a greater degree than in the paranodular thyroid tissue in seven patients, in five of whom thyroid carcinoma was subsequently identified. In five patients ${ }^{131} \mathrm{Cs}$ accumulated in both the nodule and paranodular tissue, while in the other 26 no ${ }^{131} \mathrm{Cs}$ uptake occurred in the nodule. In only one of the latter group was the thyroid lesion malignant. Caesium scanning seems to offer a useful supplementary procedure in the investigation of thyroid nodules.
\end{abstract}

\section{Introduction}

Though organ scanning is proving increasingly popular as a routine investigation for demonstrating space-filling lesions, this procedure does lack specificity when the radionuclides at present commonly available are used. Considerable attention is

* Physician in Thyroid Endocrinology and Nuclear Medicine.

$\dagger$ Honorary Assistant Physician in Nuclear Medicine.

Honorary Surgeon. Prince of Wales Hospital, Randwick, N.S.W., and the University of New
South Wales School of Medicine, Sydney. therefore being paid to the development of tumour-seeking isotopes. Several radionuclides have been studied in the past in the hope that specific localization in tumours might be achieved, but few have proved useful. Radioactive ionic caesium ( ${ }^{131} \mathrm{Cs}$ ), used by Charkes et al. (1965), was shown to have positive tumour localization in some patients. In similar trials by Uchiyama et al. (1969) particular attention was paid to scanning of the thyroid gland. Since these workers claimed a differential uptake of this nuclide between malignant and benign lesions of the thyroid, it seemed important to evaluate further the clinical applications of this technique. Our findings in an initial series of patients suggests that the procedure is indeed of value.

\section{Patients and Methods}

Scans of the neck were performed with a Picker Magnascanner 500 after the intravenous administration of $500 \mu \mathrm{Ci}$ caesium chloride $\left({ }^{131} \mathrm{Cs}\right)$. In an initial study of five patients in whom scans were carried out at 30-minute intervals the maximum target/non-target differentiation was observed at two hours after giving the radionuclide.

Radiocaesium scans were performed in 45 patients. In 38 of these this examination was undertaken after the demonstration with ${ }^{99 m} \mathrm{Tc}$ or ${ }^{131} \mathrm{I}$ that one or more palpable nodules 